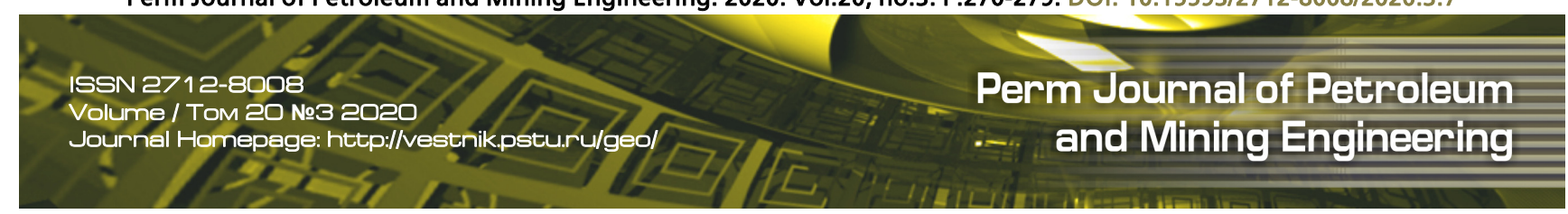

UDC 622.831 .332

Article / Статья

(c) PNRPU / ПНИПУ, 2020

\title{
Estimation of Gas Bearing Capacity and Gas Dynamic Behaviour of Rocks of Salt and Shaly-Carbonate Rock Units in the Mine Field of the Mine of the Second Mining Department of Belaruskali JSC
}

\section{Sergey S. Andreyko ${ }^{1}$, Dmitry A. Bobrov ${ }^{2}$, Egor A. Nesterov ${ }^{2}$, Elena V. Lukyanets ${ }^{1}$}

${ }^{1}$ Perm National Research Polytechnic University (29 Komsomolsky av., Perm, 614990, Russian Federation) ${ }^{2}$ Mining Institute of the Ural Branch of the Russian Academy of Sciences (78a Sibirskaya st., Building A, Perm, 614007, Russian Federation)

\section{Оценка газоносности и газодинамических характеристик пород соляных и глинисто-карбонатных пачек на шахтном поле рудника Второго рудоуправления ОАО «Беларуськалий»}

\section{С.С. Андрейко ${ }^{1}$, Д.А. Бобров ${ }^{2}$, Е.А. Нестеров ${ }^{2}$, Е.В. Лукьянец ${ }^{1}$}

${ }^{1}$ Пермский национальный исследовательский политехнический университет (Россия, 614990, г. Пермь, Комсомольский проспект, 29) ${ }^{2}$ Горный институт Уральского отделения Российской академии наук (Россия, 614007, г. Пермь, ул. Сибирская, 78а)

\section{Received / Получена: 03.02.2020. Accepted / Принята: 15.06.2020. Published / Опубликована: 17.08.2020}

Keywords:

Potash mine, gas dynamic phenomena, shaly-carbonate rock units, salt rock units, potash horizons, opening slopes, nonassociated gas bearing capacity, initial gas emission rate, nonassociated gas pressure, sealer, gas accumulations.
The paper presents results of quantitative estimations of gas bearing capacity and gas dynamic behaviour of shaly-carbonate and salt rock units along the geologic profile of the Starobinsky potash field between the III and IV potash horizons. Underground experimental studies of the gas bearing capacity and gas dynamic behaviour of the shaly-carbonate and salt unit rocks were conducted in the slopes opening the IV potash horizons in the mine field of the mine of the Second Mining Department of Belaruskali, JSC. The underground experimental research procedure provided for quantitative estimation of the following indicators: nonassociated gas bearing capacity, initial gas emission rate and gas pressure of rocks in the 12th, 10th and 8th shalycarbonate units, as well as the 11th and 9th salt units.

Based on the underground experimental research data, a quantitative estimation of the gas bearing capacity and gas dynamic behaviour of rocks in the 12th, 10th and 8th shaly-carbonate units as well as the 11th and 9th salt units was performed.

Identified were the most gas-bearing beds of rocks in the shaly-carbonate and salt rock units, as well as the pattern of changes in the gas bearing capacity and gas dynamic behaviour of rocks in the geologic profile between the III and IV potash horizons.
Ключевые слова: калийный рудник, газодинамические явления, глинисто-карбонатные пачки, соляные пачки, калийные горизонты, вскрывающие уклоны, газоносность по свободным газам, начальная скорость газовыделения, давление свободных газов, герметизатор, скопления газов.

\begin{abstract}
Приведены результаты исследований количественной оценки показателей газоносности и газодинамических характеристик пород глинисто-карбонатных и соляных пачек, расположенных по геологическому разрезу Старобинского месторождения калийных солей между III и IV калийными горизонтами. Шахтные экспериментальные исследования газоносности и газодинамических характеристик пород глинисто-карбонатных и соляных пачек проводились во вскрывающих IV калийный горизонт уклонах на шахтном поле рудника Второго рудоуправления ОАО «Беларуськалий». Методикой шахтных экспериментальных исследований предусматривалась количественная оценка следующих показателей: газоносности по свободным газам, начальной скорости газовыделения и давления свободных газов в породах 12, 10, 8-й глинисто-карбонатных пачек, а также 11-й и 9-й соляных пачек.

На основании результатов шахтных экспериментальных исследований дана количественная оценка показателей газоносности и газодинамических характеристик пород 12, 10, 8-й глинисто-карбонатных и 11, 9-й соляных пачек.

Установлены наиболее газоносные слои пород глинисто-карбонатных и соляных пачек, а также закономерности изменения газоносности и газодинамических характеристик пород по геологическому разрезу между III и IV калийными горизонтами.
\end{abstract}

Sergey S. Andreyko (Author ID in Scopus: 55922205900 (Andreyko), 6506180352 (Andreiko)) - Doctor of Engineering, Professor, Head of the Department of Development of Mineral Recourses Fields (tel.: + 00734221984 38, e-mail: ssa@mi-perm.ru). The contact person for correspondence. Dmitry A. Bobrov - Junior Researcher (tel.: +007 34221658 42, e-mail: miner@mi-perm.ru).

Egor A. Nesterov (Author ID in Scopus: 7006126508) - PhD in Engineering, Researcher (tel.: + 007342216 58 42, e-mail: mine egor@mail.ru).

Elena V. Lukyanets - Senior Lecturer at the Department of Development of Mineral Recourses Fields (tel.: + 007342 219 84 38, e-mail: LukyanecEV@yandex.ru).

Андрейко Сергей Семенович - заведующий кафедрой разработки месторождений полезных ископаемых, доктор технических наук, профессор (тел.: + 00734221984 38, e-mail: rmpi@pstu.ru). Контактное лицо для переписки.

Бобров Дмитрий Александрович - младший научный сотрудник (тел.: + 00734221658 42, e-mail: miner@mi-perm.ru).

Нестеров Егор Анатольевич - научный сотрудник, кандидат технических наук (тел.: + 00734221658 42, e-mail: mine_egor@mail.ru).

Лукьянец Елена Владимировна - старший преподаватель кафедры разработки месторождений полезных ископаемых (тел.: +007 3422198438 , e-mail: LukyanecEV@yandex.ru). 


\section{Introduction}

Currently, beside the rocks in the I and III potash horizons, the rocks in the 12th shalycarbonate unit are considered hazardous by gas dynamic phenomena at Belaruskali potash mines [1-15]. During the driving of slopes that open the IV potash horizon, in addition to the 12th shalycarbonate rock unit, intersected will be the 10th and 8th units, their geologic profile very similar to that of the 12th shaly-carbonate unit. The geologic profile of the shaly-carbonate rock units in the Starobinsky potash field conditions features a thin alternation of shale interbeds and dolomitecalcareous shales, non-layered and slightly layered rocks, sandstone and siltstone beds, rock salt beds that serve as some sort of gas-tight screens in the unit upper part, and organic matter in the rocks (up to $1 \%$ ) in the unit rocks. All these geologic profile features of the shaly-carbonate units enable us to provide for the nonassociated gas formation in the rock strata and, thus, the formation of nearcontact and focal accumulations of the nonassociated gases. The latter may serve as seats of the gas dynamic phenomena during mining operations, i.e. the driving of opening slopes. The rocks of the 11th, 9th and 7th salt units contain beds and interbeds of non-salt rocks, halopelite, its thickness varying from a fraction of a millimetre to tens of centimetres. As evidenced in the practice of potash mining, these halopelite beds and interbeds may be associated with the near-contact accumulations of the nonassociated gas that may also serve as seats of the gas dynamic phenomena, such as a sudden rock burst (failure) of the roof (soil) of the mine workings accompanied by gas emissions. Years-long mining practice in formations with gas dynamic hazards has proved that only an in-depth study of the gas bearing capacity and gas dynamic behaviour of the shaly-carbonate and salt rocks will underpin safe working driving procedures in the gas-bearing rock [16-47].

To ensure safety of the mining operations, temporary recommendations were elaborated for safe mining during driving of opening slopes in the 12th, 10th and 8th shaly-carbonate rock units and the 11th, 9th and 7th salt rock units at the opening of the IV potash horizon in the mine field of the mine of the Second Mining Department (2nd MD) of Belaruskali. The recommendations included the parameters of the preventive gas-drainage drilling and drilling/blasting operations for torpedoing and gas-draining of the marginal area of slopes at the appearance of the gas dynamic phenomena precursors, as well as guidelines on the monitoring of warning signs and precursors of the gas dynamic phenomena. In addition, certain scientific support at driving of opening slopes is provided for, which consists in researching the gas bearing capacity and gas dynamic behaviour of the rocks in the 12th, 10th and 8th shaly-marl horizons and the 11th, 9th and 7th salt horizons for the timely adjustment and refinement of procedures to ensure a safe driving of slopes that open the IV potash horizon in the mine field of the 2 nd MD mine.

\section{Geologic Profile of the 12th, $10^{\text {th }}$ and 8th Shaly-Carbonate Rock Units and the 11th, 9th And 7th Salt Rock Units}

The geologic profile of the rock strata separating the III and IV potash horizons at the opening slope driving area is shown in Figure (a) [48-50]. The data in the Figure shows the thickness of the 12th, 10th and 8th shalycarbonate rock units is $22.7,19.4$ and $32.1 \mathrm{~m}$, respectively, while the thickness of the 11 th, 9th and 7th salt rock units is 28.2, 44.6 and $28.5 \mathrm{~m}$, respectively. Within the Starobinsky potash field, the 12th shaly-carbonate unit was opened by wells located mainly in the field's west and edge marginal parts.

A distinctive feature of the rock unit consists in its great thickness with a regular gradual change. The maximum thickness (45.73-46.02 m) is observed in the unit's north and north-east of the Starobinsky field. In the south and south-west, there is a gradual decrease in thickness: first to $35.60-38.90 \mathrm{~m}$, then to $28.0-33.41 \mathrm{~m}$, finally, in the field's western periphery, and in the southern half of the central area its thickness goes as low as $23.95-25.0 \mathrm{~m}$. The unit's minimum thickness $(20.95 \mathrm{~m})$ is in the south of the western periphery and in the south of the main area. Therefore, from the north-east to the south-west, the unit's thickness is reduced by half, going down from 45.78-46.02 $\mathrm{m}$ to $20.95 \mathrm{~m}$.

Normally, the geologic profile of the 12th shaly-carbonate rock unit features four beds. The unit is distinct in thick sandstone interbeds at the base of some beds, as well as an overall increase in sandy and silty fractions in the terrigenous rock composition. The first (lower) bed has an average thickness of $4.0-5.0 \mathrm{~m}$. A slightly increased thickness $(7.5-6.0 \mathrm{~m})$ is observed in the north and north-east of the field. The first bed features a 
reduced thickness $(2.0-3.5 \mathrm{~m})$ in the south and south-east of the field. The lower part of the first bed is composed of alternating thin beds (from several $\mathrm{mm}$ to $2-3 \mathrm{~cm}$ ) of dolomite marl and shale of varying carbonate contents. There are one millimetre-thick interbeds of yellowish-grey siltstone, and carbonate-anhydrite and peliticanhydrite rocks. The upper part of the first bed is composed of dark grey marl that is dense and indistinctly layered with sandstone interbeds.

The second bed differs from the first one by the presence (in its lower part) of a sandstone bed with a thickness between 1.5 and $6.0 \mathrm{~m}$. The thickness of the sandstone bed, as well as the total thickness of the bed, increases from the south to the north. The sandstone has a yellowish or brownish-grey colour, is fine- and small-grained, with inclusions of coarse grains of quartzfeldspathic composition. The sandstone's texture is layered, cemented by halite. The upper half of the bed features multiple pockets of anhydrite. Mottled clay passing in interbeds into dolomite marl is above the sandstone bed. Anhydrite interbeds of up to several centimetres thick are found occasionally. The unit ends up with shaly-marl rocks with interbeds of rock salt and occasional interbeds of anhydrite. The second bed thickness varies between 5.6-7.0 $\mathrm{m}$ in the field's south-east and west and $11.0-15.2 \mathrm{~m}$ in the field's north.

The third bed at its base also has a sandstone bed that passes into siltstone in the field's western periphery and the north. The bed's thickness is $0.4 \mathrm{~m}$ in the field's west, $1.7-2.2 \mathrm{~m}$ in the south and south-east, and $6.2 \mathrm{~m}$ in the north. The sandstone has a pinkish-grey and grey colour, and is cemented by halite. Above the sandstone there is a shale/dolomite marl alternation area. The shale beds are $1 \mathrm{~mm}$ to $10 \mathrm{~cm}$ thick, the thickness of marl is $1 \mathrm{~mm}$ to $20 \mathrm{~cm}$. The shale is occasionally sandy. In the upper part of the bed, the shale passes into shaly-marl, which is indistinctly layered and occasionally silty. There are sporadic beds of siltstone (up to $2 \mathrm{~cm}$ thick), and less frequent beds of anhydrite (up to $0.5 \mathrm{~cm}$ thick). The third bed ends up with a bed of rock salt with a thickness of 2.0-3.6 m. There is no rock salt bed in the field's western periphery. The third bed's thickness also changes sharply: in the southern and western periphery of the field, the thickness is 7.2-9.6 m, while in the north and north-east, it amounts to $14.6-17.0 \mathrm{~m}$. The decrease in thickness in the third bed is mainly due to its non-salt section and partly owing to the absence of a rock salt bed in the bed's roof in the field's western periphery only.

Upper and lower parts composed of different rock types can be identified in the unit's fourth (upper) bed in the field's northern and western periphery only, which is not feasible for the field's south. The description of the latter, therefore, only includes silty shale with rock salt interbeds. In the northern and western periphery of the field, these shales compose the fourth bed's upper part, while in the lower part there are interbeds of dolomiteanhydrite rock and sandstone interbeds. The thickness of the top bed varies between $2.7-3.0 \mathrm{~m}$ in the field's south-east and 3.2-7.6 $\mathrm{m}$ in the south and west. In the north and north-east, the thickness of the unit's fourth layer increases to 7.9-12.0 m.

In general, the change in each bed's thickness in the rock unit is subject to a general pattern of its increase from the south-west to the north-east. The thickness changes in the 12th shaly-carbonate unit owing to the change in the thickness of each bed, while the number of beds in the unit remains the same over its entire spread.

The 10th and 8th shaly-carbonate units down the geologic profile were opened by a limited number of wells located in the western half of the field and its marginal northern and southern parts. Over the whole area (except for the south-east), the thickness of the 10th shaly-carbonate unit remains more or less constant, amounting to 19.4-23.7 $\mathrm{m}$, and only in the south-east it increases to $27.5-30.3 \mathrm{~m}$, while in the south-west (well No. 142) it decreases to $17.0 \mathrm{~m}$. There are three beds in the structure of the 10th and 8th shaly-carbonate units, so these units, just as the 12th unit, are classified as complex ones, according to their geologic profile. Normally, the lower part of the first bed of these rock units is composed of shales alternating with dolomitecalcareous mudrocks, and forms approximately $40-50 \%$ of the total bed thickness. Above are nonlayered and slightly layered shaly-marl rocks, their thickness amounting to $30-40 \%$ of the total bed thickness. Typically, sandstone and siltstone beds adjoin the top of these rocks. The bed's uppermost part (10-15\% of the total thickness) is composed of the rocks with a high content of calcium sulphate, dolomite and calcite. In general, the rock in the lower part has a layered structure. The upper parts of the beds are composed of shalymarl rocks, almost non-layered or slightly layered, with only a few interbeds of argillaceous calcareous dolomite, dolomite calcareous marls 

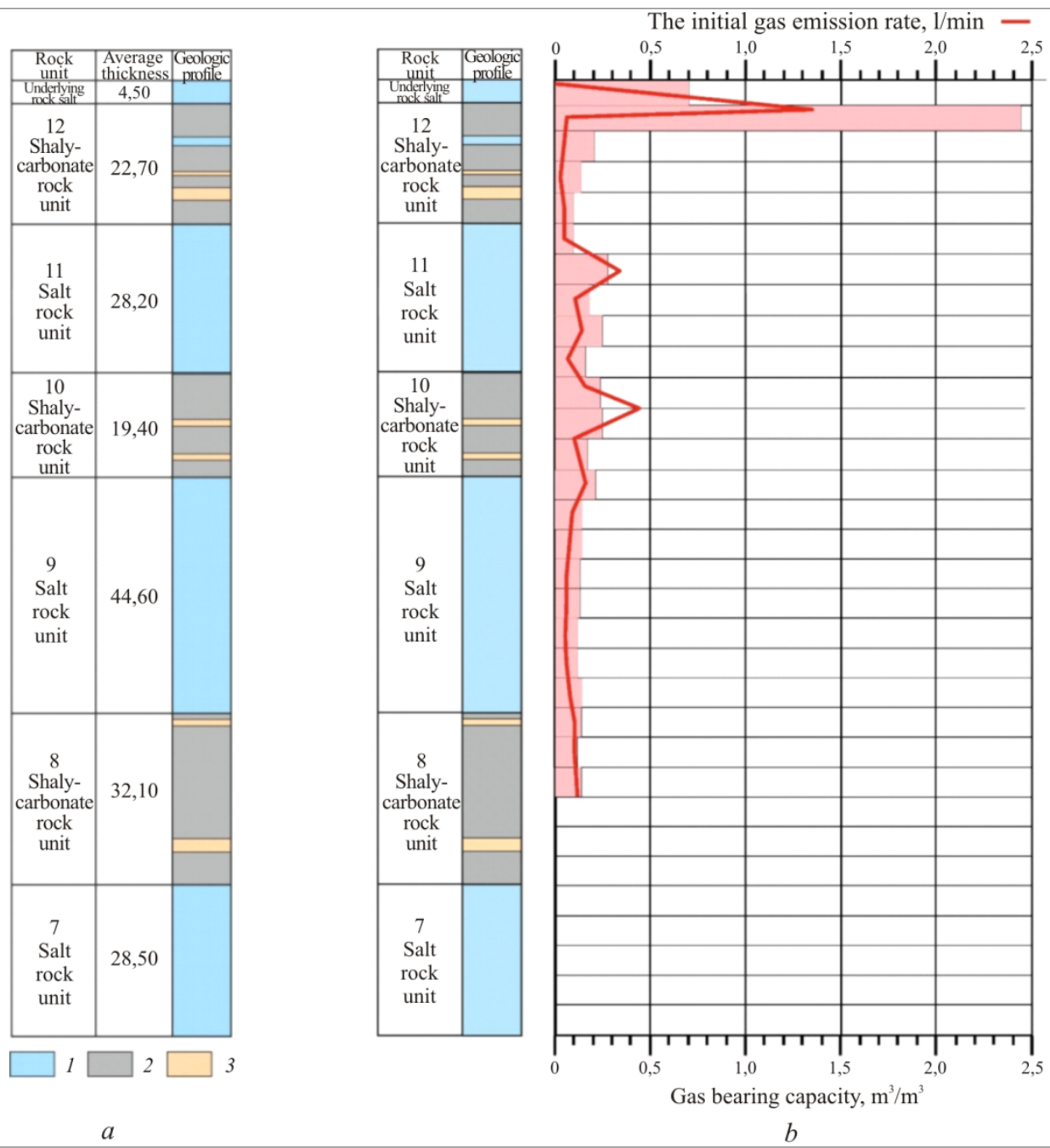

Fig. Potash horizons III and IV: $a$ is the geologic profile of the rock thickness separating the III and IV potash horizons in the section of driving opening slopes in the mine field of the 2nd MD mine: 1 is rock salt; 2 is shale/ marl alternation; 3 shows sandstones; $b$ is the gas bearing capacity of rocks and initial gas emission rate in wells through the rock strata section between the III and IV potash horizons

and shales. The upper parts of the shaly-carbonate units feature a more homogeneous composition.

The first (lower) bed of the unit in the western periphery part is $8.7-10.0 \mathrm{~m}$ thick. In the field's north, north-east and centre, the thickness of the first bed is 6.7-8.4 m, while in the east it decreases to $3.2 \mathrm{~m}$. The lower part of the first bed with a thickness of 3-5 $\mathrm{m}$ is composed of shales of dark grey colour tending to green, and interbeds of carbonate-anhydrite rocks.

According to data of well No. 396, the thickness of the 10th shaly-carbonate unit is 19.4 $\mathrm{m}$. The unit is represented by alternating massive shale of dark grey, greenish-grey and greyishbrown colours. Interbeds of small-grained sandstone are identified at intervals of 60.6-60.8 $\mathrm{m}$ and $66.9-67.2 \mathrm{~m}$. The thickness of the 8th shaly-carbonate unit is $32.10 \mathrm{~m}$; the unit is composed of alternating interbeds of massive shale of dark grey and greyish-brown colours with interbeds of greenish-grey marl. Finegrained sandstone interbeds are identified at intervals of $120.55-120.59 \mathrm{~m}, 143.20-143.40 \mathrm{~m}$, and $144.55-144.90 \mathrm{~m}$.

The 11th, 9th and 7th salt units are mainly represented by the rock salt containing beds and interbeds of non-salt rocks - halopelites, their thickness varying between a fraction of a millimetre to $0.15 \mathrm{~m}$. As such, the 11 th salt unit with a thickness of $28.20 \mathrm{~m}$ is represented by the rock salt of light grey to dark grey colours. The dark grey colour of the rock salt is due to the admixed shale material. The rock salt has a medium- and coarse-crystalline texture. Dark grey shale interbeds of a thickness ranging between a few millimetres and $0.10 \mathrm{~m}$ can be 
found across the entire thickness of the unit. The underlying 9th salt unit with a thickness of $44.60 \mathrm{~m}$ is represented by alternating interbeds of medium- and coarse-crystalline rock salts of grey and dark grey colours. In the second half of the thickness interval, there are interbeds of finely-crystalline rock salts of the yellowishgreyish colour. The dark grey shale interbeds with a thickness ranging between several millimetres and $0.15 \mathrm{~m}$ are found across the entire thickness of the 9th unit. The upper part of the 7th salt unit with a thickness of $5.83 \mathrm{~m}$ is represented by the grey rock salt with dark grey shale interbeds. The presence of shale beds and interbeds with a thickness up to $0.15 \mathrm{~m}$ in the rocks of the salt units indicates possible nearcontact accumulations of nonassociated gases.

\section{Study Procedure of Gas Bearing Capacity and Gas Dynamic Behaviour of Rocks of the 12th, 10th and 8th Shaly-Carbonate Units and the 11th, 9th and 7th Salt Units}

The gas bearing capacity of the underlying rock salt of the 12th, 10th and 8th shalycarbonate units and the 11th, 9th and 7th salt units was studied by sampling and performance measurements of the gas emitted from research wells $[51,52]$. During the driving of the slopes that open the IV potash horizons, the wells were drilled by intervals into the floor, perpendicular to the bedding. The drilling interval was $1.0 \mathrm{~m}$. The drilling assembly was then removed followed by the well sealing at $0.5 \mathrm{~m}$ off the bottom. The gas released from the walls and bottom of the sealed part of the borehole goes into a gas outlet connected to DPI-740 digital portable precision pressure indicator designed for laboratory and field applications. The barometer's high accuracy and repeatability ensure its application as a reference pressure gauge or absolute pressure indicator, if necessary.

DPI-740 determines the initial gas emission rate in the well by the pressure created by the gas passing through the calibrated capillary aperture, as well as the gas pressure increment in the well within 30 seconds after it is sealed, i.e. the initial gas pressure. Gas bearing performance is determined based on this reading, using preplotted dependency graphs of $X=f\left(P_{r}\right)$, where $X$ is the rock gas bearing capacity, $\mathrm{m}^{3} / \mathrm{m}^{3} ; P_{g}$ is the initial gas pressure [21].

\section{Results of Experimental Studies of Gas Bearing Capacity and Gas Dynamic Behaviour of Rocks During Interval Driving of Opening Slopes at the Mine Field of the 2nd MD Mine}

During the driving of the transport conveyor and ventilation slopes that open the IV potash horizon in the mine field of the 2MD mine, 14 wells were drilled to determine the gas bearing capacity and gas dynamic behaviour of the rocks of the underlying rock salt bed and the 12th shalycarbonate unit, as well as five sets of three wells in each to study the rock gas bearing capacity of the 10th and 8th shaly-carbonate units and the 11th and 9th salt units. A total of 29 research wells were drilled in scientific support of the opening slope driving. The value distribution of the nonassociated gas and initial gas emission rates in the research wells through the geologic profile of the rock thickness between the III and IV potash horizons in the mine field of the 2nd MD mine is shown in Figure, $b$. The Figure shows that in the depth interval of $0.5-1.0 \mathrm{~m}$, the gas bearing capacity was $0.54 \mathrm{~m}^{3} / \mathrm{m}^{3}$. At this drilling depth there is a contact between a bed of the underlying rock salt and the 12th shalycarbonate unit. The initial nonassociated gas emission rate in this depth range was $0.62 \mathrm{l} / \mathrm{min}$, while the nonassociated gas pressure at this depth amounted to $0.196 \mathrm{MPa}$.

At a depth of $1.5 \mathrm{~m}$, which corresponds to a sealing depth of $1.0-1.5 \mathrm{~m}$, the bedrock gas bearing capacity was $2.44 \mathrm{~m}^{3} / \mathrm{m}^{3}$, while the initial gas emission rate was $1.331 / \mathrm{min}$, and the nonassociated gas pressure in the bedrock mass was $0.23 \mathrm{MPa}$. At this drilling depth there is a fourth (upper) bed of the 12th shaly-carbonate unit with a thickness of $6.1 \mathrm{~m}$, represented by an alternation of dark grey marl and indistinctly layered, dense dark grey shale. The open porosity of rocks in this bed of the 12th shalycarbonate unit varies between 5.6 and $11.0 \%$ with an average value of $8 \%$. In this rock bed, the experimental works in the research wells proved the high probability of identifying the nonassociated gas accumulations. Further drilling and studies of the gas bearing capacity and gas dynamic behaviour of the rocks showed that down through the geologic profile, the gas bearing capacity of the rocks in the 12 th shalycarbonate unit did not exceed $0.21 \mathrm{~m}^{3} / \mathrm{m}^{3}$, the initial gas emission rate was no larger than 
$0.16 \mathrm{l} / \mathrm{min}$, and the maximum nonassociated gas pressure was $0.19 \mathrm{MPa}$.

In the rocks of the 11th salt unit, the nonassociated gas bearing capacity ranged between 0.1 and $0.29 \mathrm{~m}^{3} / \mathrm{m}^{3}$, and the initial gas emission rate varied between 0.05 and $0.33 \mathrm{l} / \mathrm{min}$. The maximum values of the gas bearing capacity $\left(0.29 \mathrm{~m}^{3} / \mathrm{m}^{3}\right)$ and initial gas emission rate $(0.33 \mathrm{l} / \mathrm{min})$ were observed in the middle beds of the 11th salt unit and related to halopelite interbeds. The nonassociated gas pressure in the rock mass of the 11th salt unit does not exceed 0.192 MPa.

In the geologic profile of the 10th shalycarbonate unit, the gas bearing capacity and gas dynamic behaviour of the rocks vary nonuniformly: the nonassociated gas bearing capacity varies between 0.10 and $0.25 \mathrm{~m}^{3} / \mathrm{m}^{3}$, the initial rate of the nonassociated gas emission ranges between 0.03 and $0.411 / \mathrm{min}$, while the nonassociated gas pressure in the rock mass does not exceed $0.192 \mathrm{MPa}$. The most gas bearing rocks are those occurring in the interval of 4.0-5.0 m from the roof of the 10th shalycarbonate unit. Within this interval of the unit's geologic profile, the nonassociated gas bearing capacity varies between 0.21 and $0.25 \mathrm{~m}^{3} / \mathrm{m}^{3}$. The maximum values of the initial gas emission rate and nonassociated gas pressure in the rock mass of the 10th shaly-carbonate unit are limited to the same interval.

The experimental studies of the gas bearing capacity and gas dynamic behaviour of the rocks in the 9th salt unit showed that the rocks are slightly gassy, their nonassociated gas bearing capacity varies between 0.1 and $0.18 \mathrm{~m}^{3} / \mathrm{m}^{3}$, while the initial rate of the nonassociated gas emission ranges between 0.03 and $0.15 \mathrm{l} / \mathrm{min}$. The nonassociated gas pressure in the rock mass of the 9th salt unit does not exceed 0.19 MPa.

The nonassociated gas bearing capacity of the rocks in the 8th shale-carbonate unit varies between 0.10 and $0.14 \mathrm{~m}^{3} / \mathrm{m}^{3}$. The initial rate of the nonassociated gas emissions falls within the range between 0.03 and $0.13 \mathrm{l} / \mathrm{min}$. The nonassociated gas pressure in the rock mass does not exceed $0.19 \mathrm{MPa}$. No near-contact nonassociated gas accumulations were detected at the contact between the 9th salt unit and the 8th shaly-carbonate unit. The rock's gas bearing capacity in the 8th shaly-carbonate unit at the contact with the 9th salt unit is much lower than that by the nonassociated gas in the rocks of the 12th shaly-carbonate unit, that is 10 times more hazardous due to the gas dynamic phenomena in the mine field of the 2nd MD mine.

The study results of the gas bearing capacity and gas dynamic behaviour of the rocks during driving of slopes that open the IV potash horizon in the mine field of the 2nd MD mine show that the most gas-bearing rocks are those of the fourth (upper) bed with a thickness of $6.1 \mathrm{~m}$, pertaining to the 12th shaly-carbonate unit, which is classified as hazardous by the gas dynamic phenomena. In this bed of the 12th shalycarbonate unit rocks, there is a high likelihood of the nonassociated gas accumulations that under certain mining conditions may be the seats of the gas dynamic phenomena.

Based on the study results of the gas bearing capacity and gas dynamic behaviour of the rocks of the salt and shaly-carbonate units, to ensure the safety of mining operations, an operating procedure has been developed for driving the opening slopes of the 12th, 10th and 8th shalycarbonate units and the 11th, 9th and 7th salt units at the opening of the IV potash horizon in the mine field of the 2nd MD mine of Belaruskali. The procedure included the application of special modes of the slope driving involving prevention methods of the gas dynamic phenomena depending on geological conditions of driving: normal driving mode in the underlying rock salt; mode of the inclined face opening of the 12th, 10th and 8th shaly-marl horizons; mode of the inclined intersection of the 12th, 10th and 8th shaly-marl horizons; mode of driving along the 11th, 9th and 7th salt horizons; mode of the intersecting zones hazardous due to the gas dynamic phenomena, when precursors thereof appear [53, 54]. Special slope driving modes subject to geological conditions provide for the inclined face drilling of exploration and gas drainage boreholes, preventive gas drainage drilling, drilling and blasting operations for torpedoing and gas-draining of the marginal area of slopes at the appearance of the gas dynamic phenomena precursors, as well as the guidelines on the monitoring of warning signs and precursors of the gas dynamic phenomena.

\section{Conclusions}

The following conclusions can be drawn based on the data of the experimental studies of the nonassociated gas bearing capacity and gas dynamic behaviour of shaly-carbonate and salt 
rocks of the strata separating the III and IV potash horizons in the slopes opening the IV potash horizon at the mine field of the 2nd MD mine:

1. The most gas bearing rocks are those pertaining to the fourth (upper) bed of the 12th shaly-carbonate unit. Within this bed of shalycarbonate rocks, the nonassociated gas bearing capacity varies between 1.33 and $2.44 \mathrm{~m}^{3} / \mathrm{m}^{3}$, which is $12-20$ times higher than that in other beds of the 12th shaly-carbonate unit located down through the geologic profile. The maximum initial gas emission rates that are 5-8 times higher than the initial gas emission rate of other rocks in the 12th shaly-carbonate unit located down through the geologic profile, is also limited to this bed.

2. The nonassociated gas bearing capacity and gas dynamic behaviour of the rocks in the 10th and 8th shaly-marl units are significantly lower than the corresponding values of the 12th shaly-carbonate unit. The nonassociated gas bearing capacity of the rocks in the 10th and 8th shaly-carbonate units ranges between 0.10 and $0.25 \mathrm{~m}^{3} / \mathrm{m}^{3}$. The initial nonassociated gas emission rate falls within 0.03 and $0.41 \mathrm{l} / \mathrm{min}$. The nonassociated gas pressure in the mass does not exceed $0.192 \mathrm{MPa}$.

3. In the rocks of the 11th and 9th salt units, the nonassociated gas bearing capacity varies between 0.1 and $0.29 \mathrm{~m}^{3} / \mathrm{m}^{3}$, while the initial gas emission rate ranges between 0.03 and $0.33 \mathrm{l} / \mathrm{min}$. The maximum values of the gas bearing capacity $\left(0.29 \mathrm{~m}^{3} / \mathrm{m}^{3}\right)$ and the initial gas emission rate $(0.33 \mathrm{l} / \mathrm{min})$ are limited to halopelite interbeds. The nonassociated gas pressure in the rocks of the 11th and 9th salt units does not exceed 0.192 MPa.

4. Based on the data of the gas bearing capacity and gas dynamic behaviour studies of the rocks in the salt and shaly-carbonate units, to ensure the safety of mining operations, an operating procedure has been developed for driving the opening slopes of the 12th, 10th and 8th shaly-carbonate units and 11th, 9th and 7th salt units at the opening of the IV potash horizon in the mine field of the 2nd MD mine of Belaruskali.

\section{References}

1. Proskuriakov N.M. Upravlenie sostoianiem massiva gornykh porod [Controlling the state of the rock mass]. Moscow: Nedra, 1991, 368 p.

2. Andreiko S.S., Kalugin P.A., Shcherba V.Ia. Gazodinamicheskie iavleniia $\mathrm{v}$ kaliinykh rudnikakh: genezis, prognoz i upravlenie [Gas-dynamic phenomena in potash mines: genesis, forecast and management]. Minsk: Vysheishaia shkola, $2000,335 \mathrm{p}$.

3. Andreiko S.S., Ivanov O.V., Litvinovskaia N.A. Prognozirovanie i predotvrashchenie gazodinamicheskikh iavlenii iz pochvy pri prokhodke podgotovitel'nykh vyrabotok v podrabotannom massive solianykh porod [Prediction and prevention of gas-dynamic phenomena from the soil when driving development workings in an underworked salt massif]. Perm': Permskii natsional'nyi issledovatel'skii politekhnicheskii universitet, 2015, $159 \mathrm{p}$.

4. Tarakanov V.A. et al. Issledovaniia gazonosnosti porod plasta Tret'ego kaliinogo gorizonta Starobinskogo mestorozhdeniia [The rock gas-bearing capacity researches of the Starobin deposit third potash level seam]. Gornyi zhurnal, 2010, no. 8, pp. 25-27.

5. Beresnev S.P. et al. Issledovanie mekhanizma formirovaniia opasnykh po gazodinamicheskim iavleniiam zon $\mathrm{v}$ porodakh kaliinogo gorizonta [Research of the mechanism forming the zones that are dangerous on gas and dynamic phenomena in the first potash level rocks]. Gornyi zhurnal, 2010, no. 8, pp. 31-33.

6. Podlesnyi I.A., Beresnev S.P., Andreiko S.S., Nekrasov S.V., Litvinovskaia N.A. Geomekhanicheskoe modelirovanie vnezapnykh razrushenii porod pochvy gornykh vyrabotok [Geomechanical modeling of the sudden collapse of roadways floor rocks]. Gornyi zhurnal, 2010, no. 8, pp. 28-30.

7. Lialina T.A., Nesterov E.A., Elovikova A.S. Otsenka vozmozhnosti razvitiia gazodinamicheskikh iavlenii pri vedenii gornykh rabot na III kaliinom gorizonte Krasnoslobodskogo rudnika 2 RU [Estimation of gas and dynamic effects development's possibility while mining at the third potash level of Krasnoslobodsky mine of the 2 PU]. Gornaia mekhanika $i$ mashinostroenie: nauchno-tekhnicheskii zhurnal, 2012, no. 1, pp. 5-15.

8. Andreiko S.S., Litvinovskaia N.A. Modeling sudden failure of floor of underground excavations in undermined salt rock mass. Eurasian Mining. Tiso Print, 2015, no. 2 (24), pp. 15-17. DOI: $10.17580 / \mathrm{em} .2015 .02 .04$

9. Lialina T.A. Issledovanie zakonomernostei lokalizatsii gazovydelenii iz geologorazvedochnykh skvazhin vblizi zon zameshcheniia kaliinykh plastov [Investigation of the regularities of the localization of gas emissions from exploration wells near the zones of replacement of potash strata]. Strategiia $i$ protsessy osvoeniia georesursov. Sbornik nauchnykh trudov. Perm': Gornyi institut Ural'skogo otdeleniia Rossiiskoi akademii nauk, 2017, iss. 15, pp. 362-365.

10. Andreyko S.S., Lyalina T.A. Rocburst From Floors. Soils and Rocks. Sao Paulo, 2019, no. 42 (1), pp. 77-82. DOI: $10.28927 /$ SR.421077

11. Barbikov D.V., Andreiko S.S., Ivanov O.V., Bobrov D.A. Otsenka gazodinamicheskikh kharakteristik gornykh porod Krasnoslobodskogo razloma [Gas dynamics of rock mass at the Krasnoslobodsk fault]. Gornyi zhurnal, 2018, no. 8, pp. 38-42. DOI: $10.17580 /$ gzh.2018.08.04

12. Fedoseev A., Andreiko S. Geo mechanical Estimation of Danger of Gas-Dynamic Failure During Potash Deposits Mining. Procedia Engineering, 2017, vol. 191, pp. 954-961. DOI: 10.1016/j.proeng.2017.05.266

13. Bariakh A.A., Andreiko S.S., Fedoseev A.K. O mekhanizme lokalizatsii ochagov gazodinamicheskikh iavlenii $\mathrm{v}$ pochve sil'vinitovykh plastov [About the mechanism of localization of gas dynamic phenomena focuses in the bedrock of sylvinite formations]. Vestnik Permskogo natsional'nogo issledovatel'skogo politekhnicheskogo universiteta. Geologiia. Neftegazovoe i gornoe delo, 2017, vol. 16, no. 3, pp. 247-254. DOI: 10.15593/2224-9923/2017.3.5

14. Andreyko S.S., Ivanov O.V., Nesterov E.A., Golovatiy I.I., Beresnev S.P. Research of salt rocks gas content of III potash layer in the Krasnoslobodsky mine field. Gornyi Zhurnal. Moskow: Ruda i Metallly, 2013, no. 2, pp. 38-41.

15. Nesterov E.A. Sovershenstvovanie tekhnologii degazatsionnykh rabot pri otrabotke sil'vinitovykh plastov $\mathrm{v}$ usloviiakh shakhtnykh polei rudnikov OAO "Sil'vinit" [Improvement of decontamination works technology during sylvinite layers mining in the mine fields of "Silvinit"]. Vestnik Permskogo natsional'nogo issledovatel'skogo politekhnicheskogo universiteta. Geologiia. Neftegazovoe i gornoe delo, 2013, no. 6, pp. 120-127. DOI: $10.15593 / 2224-9923 / 2013.6 .13$

16. Fortunatov G.A., Krasiuk N.F., Zemskov A.N., Ivanov O.V. Gazonosnost' solianykh porod kaliinykh mestorozhdenii Zhilianskoe i Satimola (Kazakhstan) [Gas content of saliferous rocks of potassium deposits Zhilianskoe and Satimola (Kazakhstan)]. Vestnik Permskogo natsional'nogo issledovatel'skogo politekhnicheskogo 
universiteta. Geologiia. Neftegazovoe i gornoe delo, 2014, no. 11, pp. 88-98. DOI: 10.15593/2224-9923/2014.11.9

17. Lialina T.A., Andreiko S.S. Otsenka vozmozhnosti razvitiia gazodinamicheskikh iavlenii $\mathrm{v}$ vide vnezapnykh razrushenii porod pochvy gornykh vyrabotok, soprovozhdaiushchikhsia gazovydeleniem, v usloviiakh iuzhnoi chasti Verkhnekamskogo mestorozhdeniia [Capability assessment of gasdynamic effects development as sudden destruction of mine workings rocks of soil, accompanied by gas evolution, in conditions of the southern part of Verkhnekamskoye field]. Vestnik Permskogo natsional'nogo issledovatel'skogo politekhnicheskogo universiteta. Geologiia. Neftegazovoe i gomoe delo, 2013, no. 7, pp. 107-116. DOI: 10.15593/2224-9923/2013.7.11

18. Litvinovskaia N.A. Gazonosnost' produktivnykh plastov i vmeshchaiushchikh porod shakhtnykh polei OAO "Uralkalii" [Gas content of productive strata and enclosing rocks of mine fields of JSC Uralkali]. Strategiia $i$ protsessy osvoeniia georesursov. Sbornik nauchnykh trudov. Perm': Gornyi institut Ural'skogo otdeleniia Rossiiskoi akademii nauk, 2014, iss. 12, pp. 236-237.

19. Litvinovskaia N.A. Gazonosnost' produktivnykh plastov i vmeshchaiushchikh porod tsentral'noi chasti VKMKS [Gas content of productive strata and enclosing rocks of the central part of Upper Kama Potassium Salt Deposit]. Strategiia $i$ protsessy osvoeniia georesursov. Sbornik nauchnykh trudov. Perm': Gornyi institut Ural'skogo otdeleniia Rossiiskoi akademii nauk, 2015, iss. 13, pp. 241-243.

20. Nesterov E.A. Mekhanizm obrazovaniia vnezapnykh otzhimov prizaboinoi chasti porod $\mathrm{v}$ solianom porodnom massive [The mechanism of formation of sudden squeezing of the bottom-hole part of the rocks in the salt rock mass]. Strategiia i protsessy osvoeniia georesursov. Sbornik nauchnykh trudov. Perm: Gomyi institut Ural'skogo otdeleniia Rossiiskoi akademii nauk, 2015, iss. 13, pp. 244-246.

21. Ivanov O.V. Postroenie prognoznykh kart zon, opasnym po gazodinamicheskim iavleniiam, na vvodimykh $\mathrm{v}$ ekspluatatsiiu uchastkakh VKMKS [Creation of forecast maps of zones with gas-dynamic phenomena hazardous at the Upper Kama Potassium Salt Deposit sections being commissioned]. Strategiia i protsessy osvoeniia georesursov. Sbornik nauchnykh trudov. Perm': Gornyi institut Ural'skogo otdeleniia Rossiiskoi akademii nauk, 2015, iss. 13, pp. 235-237.

22. Nesterova S.Iu., Andreiko S.S. Tekhnologiia degazatsii vybrosoopasnogo massiva pri mekhanizirovannoi dobyche karnallita [The technology of degassing an outburst-hazardous massif during mechanized extraction of carnallite]. Estestvennye $i$ tekhnicheskie nauki, 2017, no. 2, pp. 63-67.

23. Andreiko S.S., Litvinovskaia N.A., Lialina T.A. Control of gas-dynamic processes in floor rock mass in sylvinite bed $\mathrm{AB}$ of the Upper Kama Potassium Salt Deposit. Gornyi Zhurnal. Moskow: Ruda i Metallly, 2015, no. 4, pp. 89-92. DOI: 10.17580/gzh.2015.04.16

24. Litvinovskaia N.A. Gazonosnost' i gazodinamicheskie kharakteristiki porod pochvy pri sloevoi vyemke tret'ego kaliinogo plasta v usloviiakh rudnikov OAO "Belarus'kalii" [Gas content and gas-dynamic characteristics of soil rocks during layer excavation of the third potash seam in the conditions of mines of JSC "Belaruskali"]. Strategiia i protsessy osvoeniia georesursov. Sbornik nauchnykh trudov. Perm': Gornyi institut Ural'skogo otdeleniia Rossiiskoi akademii nauk, 2016, iss. 14, pp. 315-317.

25. Andreyko S.S., Lyalina T.A. Strength-Gas relationship of sylvinite seams on verkhnekamskoye deposit. Asian Academic Research Joumal of Multidisciplinary, 2016, vol. 3, iss. 4, pp. 219-226.

26. Ivanov O.V. et al. Issledovanie gazonosnosti solianykh porod Tret'ego kaliinogo plasta na shakhtnom pole Krasnoslobodskogo rudnika [Investigation of the gas content of salt rocks of the Third potash layer in the mine field of the Krasnoslobodsky mine]. Gornyi zhumnal, 2013, no. 6, pp. 69-73.

27. Siemann M.G. Herkunft und Migration mineralgebundener Gase der Zechstein 2 Schichten in Zielits. Kali und Steinsalz, 2007, Heft 3, pp. 26-41.

28. Hedlund F.H. The extreme carbon dioxide outburst at the Menzengraben potash mine, 7 July 1953. Safety Science, 2012, vol. 50, pp. 537-553. DOI: $10.1016 /$ j.ssci.2011.10.004

29. Zhang Ch., Xia-Ting F., Hui Zh., Qiu Sh., Wu W. Case Histories of Four Extremely Intense Rockbursts in Deep Tunnels. Rock Mechanics and Rock Engineering, 2012, vol. 45 (3), pp. 275-288. DOI: 10.1007/s00603-011-0218-6
30. Prusek, S., Masny, W. Analysis of damage to underground workings and their supports caused by dynamic phenomena. Journal of Mining Science, 2015, vol. 51(1), pp. 63-72. DOI: $10.1134 /$ S1062739115010093

31. Trubetskoi K.N., Iofis M.A., Esina E.N. Osobennosti geomekhanicheskogo obespecheniia osvoeniia mestorozhdenii, sklonnykh $\mathrm{k}$ gazodinamicheskim iavleniiam [Geomechanical Service in Mining under Gas and-Dynamic Phenomena]. Fizikotekhnicheskie problemy razrabotki poleznykh iskopaemykh, 2015, no. 3, pp. 64-71.

32. Wojtecki Ł., Konicek P. Estimation of active rockburst prevention effectiveness during longwall mining under disadvantageous geological and mining conditions. Journal of Sustainable Mining, 2016, vol. 15, iss. 1, pp. 1-7. DOI: $10.1016 /$ j.jsm.2016.04.003

33. Nierobisz A. Identification of load to dog heading support during a rockburst. Journal of Mining Science, 2016, vol. 52 (6), pp. 1129-1142. DOI: 10.1134/S1062739116061662

34. Sainoki A., Mitri Hani S., Yao M., Chinnasane D. Discontinuum Modelling Approach for Stress Analysis at a Seismic Source: Case Study. Rock Mechanics and Rock Engineering. 2016, vol. 49 (12), pp. 4749-4765. DOI: 10.1007/s00603-016-1089-7

35. Vennes I., Mitri H. Geomechanical effects of stress shadow created by large-scale destress blasting. Journal of Rock Mechanics and Geotechnical Engineering, 2017, vol. 9, iss. 6, pp. 1085-1093. DOI: 10.1016/j.jrmge.2017.09.004

36. Manouchehrian A., Cai M. Analysis of rockburst in tunnels subjected to static and dynamic loads. Journal of Rock Mechanics and Geotechnical Engineering, 2017, vol. 9, iss. 6, pp. 1031-1040. DOI: 10.1016/j.jrmge.2017.07.001

37. Warren J.K. Evaporites: A compendium. Berlin: Springer, 2016, $1854 \mathrm{p}$.

38. Perera M., Ranjith P.G., Choi S.K. Coal cleat permeability for gas movement under triaxial, non-zero lateral strain condition: atheoretical and experimental study. Fuel, 2013, vol. 109, pp. 389-399. DOI: 10.1016/j.fuel.2013.02.066

39. Wang S., Elsworth D., Liu J. Rapid decompression and desorption induced energetic failure in coal. Journal of Rock Mechanics and Geotechnical Engineering, 2015, vol. 7 (3), pp. 345-350. DOI: 10.1016/j.jrmge.2015.01.004

40. Li Z., Wang E., Ou J., Liu Z. Hazard evaluation of coal and gas outbursts in a coal-mine roadway based on logistic regression model. International Journal of Rock Mechanics and Mining Sciences, 2015, vol. 80, pp. 185-195. DOI: 10.1016/j.ijrmms.2015.07.006

41. Xiaogang F., Chaohui J. The cause analysis and countermeasures of coal burst at 5868 return air way heading face in Wulan coal mine. Colliery Saf, 2013, vol. 44 (10), pp. 196-198.

42. Quanlong L., Xinchun, L. Effective stability control research of evolutionary game in China's coal mine safety supervision. Journal of Beijing Institute of Technology (Social Sciences Edition), 2015, vol. 17 (4), pp. 49-56.

43. Konicek P., Ptacek J., Waclawik P., Kajzar V. LongTerm Czech Experiences with Rockbursts with Applicability to Today's Underground Coal Mines. Rock Mechanics and Rock Engineering, 2020, vol. 52(5), pp. 1447-1458. DOI: $10.1007 / \mathrm{s} 00603-018-1489-y$

44. Forbes B., Vlachopoulos N., Diederichs M.S., Hyett A.J., Punkkinen A. An in situ monitoring campaign of a hard rock pillar at great depth within a Canadian mine. Journal of Rock Mechanics and Geotechnical Engineering, 2020, vol. 12, iss. 3, pp. 427-448. DOI: 10.1016/j.jrmge.2019.07.018

45. Małkowski P., Niedbalski Z. A comprehensive geomechanical method for the assessment of rockburst hazards in underground mining. International Journal of Mining Science and Technology. 2020. vol. 30, iss. 3, pp. 345-355. DOI: 10.1016/j.ijmst.2020.04.009

46. Zhang, Shichao, Ma, Tianhui, Tang Chun'an Microseismic Monitoring and Experimental Study on Mechanism of Delayed Rockburst in Deep-Buried Tunnels. Rock Mechanics 
and Rock Engineering, 2020, vol. 53 (6), pp. 2771-2788. DOI: $10.1007 /$ s00603-020-02069-4

47. Vysotskii E.A., Kislik V.Z., Petrova N.S. O vliianii paleotektoniki na kharakter izmeneniia sostava kaliinykh gorizontov [On the influence of paleotectonics on the nature of changes in the composition of potash horizons]. Doklady $A N$ BSSR, 1980, vol. 24, no. 8, pp. 736-739.

48. Garetskii R.G. et al. Kaliinye soli Pripiatskogo progiba [Potassium salts of the Pripyat trough]. Minsk: Nauka i tekhnika, 1984, 182 p.

49. Vysotskii V.A. et al. Kalienosnye basseiny mira [Potassiumbearing basins of the world]. Minsk: Nauka i tekhnika, 1988, $387 \mathrm{p}$.

50. Andreyko S.S., Ivanov O.V., Nesterov E.A., Litvinovskaia N.A. Issledovanie gazonosnosti produktivnykh kaliinykh plastov na novykh uchastkakh shakhtnykh polei kaliinykh rudnikov OAO "Uralkalii" i OAO "Sil'vinit" [Investigation of the gas content of productive potash seams in new areas of the mine fields of the potash mines of JSC Uralkali and JSC Silvinit]. Gornyi informatsionno-analiticheskii biulleten' (nauchno-tekhnicheskii zhurnal), 2010, no. 4, pp. 186-190.

51. Zemskov A.N., Kondrashov P.I., Travnikova L.G. Prirodnye gazy kaliinykh mestorozhdenii i mery bor'by s nimi [Natural gases from potash deposits and measures to combat them]. Perm', 2008, 414 p.

52. Andreiko S.S. Predotvrashchenie gazodinamicheskikh iavlenii pri provedenii uklonov, vskryvaiushchikh IV kaliinyi gorizont, v usloviiakh Starobinskogo mestorozhdeniia kaliinykh solei [Prevention of gas-dynamic phenomena when making slopes opening the IV potash horizon in the conditions of the Starobinskoye potash salt deposit]. Strategiia i protsessy osvoeniia georesursov. Sbornik nauchnykh trudov. Perm': Gornyi institut Ural'skogo otdeleniia Rossiiskoi akademii nauk, 2014, iss. 12, pp. 227-229.

53. Andreiko S.S. Tekhnologiia provedeniia uklonov, vskryvaiushchikh IV kaliinyi gorizont, po vybrosoopasnym porodam prokhodcheskimi kombainami izbiratel'nogo deistviia $\mathrm{v}$ usloviiakh rudnika 2 RU OAO "Belarus'kalii" [The technology of making slopes, opening the IV potash horizon, on outburst-hazardous rocks by roadheaders of selective action in the conditions of mine 2 RU JSC "Belaruskali"]. Aktual'nye problemy povysheniia effektivnosti $i$ bezopasnosti ekspluatatsii gorno-shakhtnogo i neftepromyslovogo oborudovaniia. Materialy II Mezhdunarodnoi nauchno-prakticheskoi konferentsii “Gornaia i neftianaia elektromekhanika -2015”, Perm', 2015, pp. 125-131.

\section{Библиографический список}

1. Проскуряков Н.М. Управление состоянием массива горных пород. - М.: Недра, 1991. - 368 с.

2. Андрейко С.С., Калугин П.А., Щерба В.Я. Газодинамические явления в калийных рудниках: генезис, прогноз и управление. Минск: Вышейшая школа, 2000. - 335 с.

3. Андрейко С.С., Иванов О.В., Литвиновская Н.А. Прогнозирование и предотвращение газодинамических явлений из почвы при проходке подготовительных выработок в подработанном массиве соляных пород. - Пермь: Изд-во Перм. нац. исслед. политехн. ун-та, 2015. - 159 с.

4. Исследования газоносности пород пласта Третьего калийного горизонта Старобинского месторождения / В.А. Тараканов [и др.] // Горный журнал. - 2010. - № 8. - С. 25-27.

5. Исследование механизма формирования опасных по газодинамическим явлениям зон в породах калийного горизонта / С.П. Береснев [и др.] // Горный журнал. - 2010. - № 8. - С. 31-33.

6. Геомеханическое моделирование внезапных разрушений пород почвы горных выработок / И.А. Подлесный, С.П. Береснев, С.С. Андрейко, С.В. Некрасов, Н.А. Литвиновская // Горный журнал. - 2010. - № 8. - С. 28-30.

7. Лялина Т.А., Нестеров Е.А., Еловикова А.С. Оценка возможности развития газодинамических явлений при ведении горных работ на III калийном горизонте Краснослободского рудника 2 ру // Горная механика и машиностроение: научн.-техн. журн. - 2012. - № 1. - С.5-15.

8. Андрейко С.С., Литвиновская Н.A. Modeling sudden failure of floor of underground excavations in undermined salt rock mass // Eurasian Mining. Tiso Print. - 2015. - № 2 (24). P. 15-17. DOI: 10.17580/em.2015.02.04

9. Лялина Т.А. Исследование закономерностей локализации газовыделений из геологоразведочных скважин вблизи зон замещения калийных пластов // Стратегия и процессы освоения георесурсов: сб. науч. тр. - Пермь: Изд-во ГИ УрО РАН, 2017. - Вып. 15. - С. 362-365.

10. Andreyko S.S., Lyalina T.A. Rocburst From Floors / Soils and Rocks // Sao Paulo. - 2019. - № 42 (1). - P. 77-82. DOI: $10.28927 /$ SR.421077

11. Оценка газодинамических характеристик горных пород Краснослободского разлома / Д.В. Барбиков, С.С. Андрейко, О.В. Иванов, Д.А. Бобров // Горный журнал. 2018. - № 8. - C. 38-42. DOI: 10.17580/gzh.2018.08.04

12. Fedoseev A., Andreiko S. Geo mechanical Estimation of Danger of Gas-Dynamic Failure During Potash Deposits Mining // Procedia Engineering. - 2017. - Vol. 191. - P. 954-961. DOI: $10.1016 /$ j.proeng.2017.05.266

13. Барях А.А., Андрейко С.С., Федосеев А.К. О механизме локализации очагов газодинамических явлений в почве сильвинитовых пластов // Вестник Пермского национального исследовательского политехнического университета. Геология. Нефтегазовое и горное дело. - 2017. - Т. 16, № 3. - С. 247-254. DOI: $10.15593 / 2224-9923 / 2017.3 .5$

14. Research of salt rocks gas content of III potash layer in the Krasnoslobodsky mine field / S.S.Andreyko, O.V. Ivanov, E.A. Nesterov, I.I. Golovatiy, S.P. Beresnev // Gornyi Zhurnal. Moskow: Izdatel'stvo Ruda i Metallly, 2013. - № 2. - P. 38-41.

15. Нестеров Е.А. Совершенствование технологии дегазационных работ при отработке сильвинитовых пластов в условиях шахтных полей рудников ОАО «Сильвинит» // Вестник Пермского национального исследовательского политехнического университета. Геология. Нефтегазовое и горное дело. - 2013. № 6. - C. 120-127. DOI: 10.15593/2224-9923/2013.6.13

16. Газоносность соляных пород калийных месторождений Жилянское и Сатимола (Казахстан) / А.Н. Земсков, О.В. Иванов, Н.Ф. Красюк, Г.А. Фортунатов // Вестник Пермского национального исследовательского политехнического университета. Геология. Нефтегазовое и горное дело. - 2014. № 11. - С. 88-98. DOI: 10.15593/2224-9923/2014.11.9

17. Лялина Т.А., Андрейко С.С. Оценка возможности развития газодинамических явлений в виде внезапных разрушений пород почвы горных выработок, сопровождающихся газовыделением, в условиях южной части Верхнекамского месторождения // Вестник Пермского национального исследовательского политехнического университета. Геология. Нефтегазовое и горное дело. - 2013. - № 7. C. 107-116. DOI: 10.15593/2224-9923/2013.7.11

18. Литвиновская Н.А. Газоносность продуктивных пластов и вмещающих пород шахтных полей ОАО «Уралкалий» // Стратегия и процессы освоения георесурсов: сб. науч. тр. Пермь: Изд-во ГИ УрО РАН, 2014. - Вып. 12. - С. 236-237.

19. Литвиновская Н.А. Газоносность продуктивных пластов и вмещающих пород центральной части ВКМКС // Стратегия и процессы освоения георесурсов: сб. науч. тр. - Пермь: Изд-во ГИ УрО РАН, 2015. - Вып. 13. - С. 241-243.

20. Нестеров Е.А. Механизм образования внезапных отжимов призабойной части пород в соляном породном массиве // Стратегия и процессы освоения георесурсов: сб. науч. тр. Пермь: Изд-во ГИ УрО РАН, 2015. - Вып. 13. - С. 244-246.

21. Иванов О.В. Построение прогнозных карт зон, опасным по газодинамическим явлениям, на вводимых в эксплуатацию участках ВКМКС // Стратегия и процессы освоения георесурсов: сб. науч. тр. - Пермь: Изд-во ГИ УрО РАН, 2015. - Вып. 13. - С. 235-237.

22. Нестерова С.Ю., Андрейко С.С. Технология дегазации выбросоопасного массива при механизированной добыче карналлита // Естественные и технические науки. 2017. - № 2. - С. 63-67.

23. Андрейко С.С., Литвиновская Н.А., Лялина Т.A. Control of gas-dynamic processes in floor rock mass in sylvinite bed $A B$ of 
the Upper Kama Potassium Salt Deposit // Gornyi Zhurnal. Moskow: Izdatel'stvo Ruda i Metallly, 2015. - № 4. - P. 89-92. DOI: $10.17580 /$ gzh.2015.04.16

24. Литвиновская Н.А. Газоносность и газодинамические характеристики пород почвы при слоевой выемке третьего калийного пласта в условиях рудников ОАО «Беларуськалий» // Стратегия и процессы освоения георесурсов: сб. науч. тр. Пермь: Изд-во ГИ УрО РАН, 2016. - Вып. 14. - С. 315-317.

25. Andreyko S.S., Lyalina T.A. Strength-Gas relationship of sylvinite seams on verkhnekamskoye deposit // Asian Academic Research Journal of Multidisciplinary. - 2016. - Vol. 3, iss. 4. - P. 219-226.

26. Исследование газоносности соляных пород Третьего калийного пласта на шахтном поле Краснослободского рудника / О.В. Иванов [и др.] // Горный журнал. - 2013. - № 6. - С. 69-73.

27. Siemann M.G. Herkunft und Migration mineralgebundener Gase der Zechstein 2 Schichten in Zielits // Kali und Steinsalz. 2007. - Heft 3. - S. 26-41.

28. Hedlund F.H. The extreme carbon dioxide outburst at the Menzengraben potash mine, 7 July 1953 // Safety Science. - 2012. Vol. 50. - P. 537-553. DOI: 10.1016/j.ssci.2011.10.004

29. Case Histories of Four Extremely Intense Rockbursts in Deep Tunnels / Ch. Zhang, F. Xia-Ting, Zh. Hui, Sh. Qiu, W. Wu // Rock Mechanics and Rock Engineering. - 2012. - Vol. 45 (3). P. 275-288. DOI: 10.1007/s00603-011-0218-6

30. Prusek, S., Masny, W. Analysis of damage to underground workings and their supports caused by dynamic phenomena // Journal of Mining Science. - 2015. - Vol. 51 (1). P. 63-72. DOI: 10.1134/S1062739115010093

31. Трубецкой К.Н., Иофис М.А., Есина Е.Н. Особенности геомеханического обеспечения освоения месторождений, склонных к газодинамическим явлениям // Физико-технические проблемы разработки полезных ископаемых. - 2015. - № 3. - С. 64-71.

32. Wojtecki Ł., Konicek P. Estimation of active rockburst prevention effectiveness during longwall mining under disadvantageous geological and mining conditions // Journal of Sustainable Mining. - 2016. - Vol. 15, iss. 1. -P. 1-7. DOI: $10.1016 /$ j.jsm.2016.04.003

33. Nierobisz A. Identification of load to dog heading support during a rockburst // Journal of Mining Science. - 2016. Vol. 52 (6). - P.1129-1142. DOI: 10.1134/S1062739116061662

34. Discontinuum Modelling Approach for Stress Analysis at a Seismic Source: Case Study / A. Sainoki, Mitri, S. Hani, M. Yao, D. Chinnasane // Rock Mechanics and Rock Engineering. - 2016. Vol. 49 (12). - P. 4749-4765. DOI: 10.1007/s00603-016-1089-7

35. Vennes I., Mitri H. Geomechanical effects of stress shadow created by large-scale destress blasting // Journal of Rock Mechanics and Geotechnical Engineering. - 2017. - Vol. 9, iss. 6. P. 1085-1093. DOI: 10.1016/j.jrmge.2017.09.004

36. Manouchehrian A., Cai M. Analysis of rockburst in tunnels subjected to static and dynamic loads // Journal of Rock Mechanics and Geotechnical Engineering. - 2017. - Vol. 9, iss. 6. - P. 1031-1040. DOI: 10.1016/j.jrmge.2017.07.001

37. Warren J.K. Evaporites: A compendium. - Berlin: Springer, 2016. - $1854 \mathrm{p}$.

38. Perera M., Ranjith P.G., Choi S.K. Coal cleat permeability for gas movement under triaxial, non-zero lateral strain condition: atheoretical and experimental study // Fuel. 2013. - Vol. 109. - P. 389-399. DOI: 10.1016/j.fuel.2013.02.066

39. Wang S., Elsworth D., Liu J. Rapid decompression and desorption induced energetic failure in coal // J. Rock. Mech. Geotech. Eng. - 2015. - Vol. 7 (3). - P. 345-350. DOI: 10.1016/j.jmge.2015.01.004
40. Hazard evaluation of coal and gas outbursts in a coalmine roadway based on logistic regression model / Z. Li, E. Wang, J. Ou, Z. Liu // International Journal of Rock Mechanics and Mining Sciences. - 2015. - Vol. 80. - P. 185-195. DOI: 10.1016/j.ijrmms.2015.07.006

41. Xiaogang F., Chaohui J. The cause analysis and countermeasures of coal burst at 5868 return air way heading face in Wulan coal mine // Colliery Saf. - 2013. - Vol. 44 (10). P. 196-198.

42. Quanlong L., Xinchun, L. Effective stability control research of evolutionary game in China's coal mine safety supervision // J. Beijing Inst. Technol. - 2015. - Vol. 17(4). - P. 49-56.

43. Long-Term Czech Experiences with Rockbursts with Applicability to Today's Underground Coal Mines / P. Konicek, J. Ptacek, P. Waclawik, V. Kajzar // Rock Mechanics and Rock Engineering. - 2020. - Vol. 52 (5). - P.1447-1458. DOI: $10.1007 / \mathrm{s} 00603-018-1489-y$

44. An in situ monitoring campaign of a hard rock pillar at great depth within a Canadian mine / B. Forbes, N. Vlachopoulos, M.S. Diederichs, A.J. Hyett, A. Punkkinen // Journal of Rock Mechanics and Geotechnical Engineering. - 2020. - Vol. 12, iss. 3. - P. 427-448. DOI: 10.1016/j.jrmge.2019.07.018

45. Małkowski P., Niedbalski Z. A comprehensive geomechanical method for the assessment of rockburst hazards in underground mining // International Journal of Mining Science and Technology. - 2020. - Vol. 30, iss. 3. - P. 345-355. DOI: 10.1016/j.jimst.2020.04.009

46. Chun'an Microseismic Monitoring and Experimental Study on Mechanism of Delayed Rockburst in Deep-Buried Tunnels / Zhang, Shichao, Ma, Tianhui, Tang // Rock Mechanics and Rock Engineering. - 2020. - Vol. 53 (6). - P. 2771-2788. DOI: $10.1007 / \mathrm{s} 00603-020-02069-4$

47. Высоцкий Э.А., Кислик В.З., Петрова Н.С. О влиянии палеотектоники на характер изменения состава калийных горизонтов // Докл. АН БССР. - 1980. - Т. 24, № 8. - С. 736-739.

48. Калийные соли Припятского прогиба / Р.Г. Гарецкий [и др.]. - Минск: Наука и техника, 1984. - 182 с.

49. Калиеносные бассейны мира / В.А. Высоцкий [и др.]. - Минск: Наука и техника, 1988. - 387 с.

50. Иванов О.В., Нестеров Е.А., Литвиновская Н.А. Исследование газоносности продуктивных калийных пластов на новых участках шахтных полей калийньх рудников ОАО «Уралкалий» и ОАО «Сильвинит» // Горный информационно-аналитический бюллетень (научно-технический журнал). - 2010. - № 4. - С.186-190.

51. Земсков А.Н., Кондрашов П.И., Травникова Л.Г. Природные газы калийных месторождений и меры борьбы с ними. - Пермь, 2008. - 414 с.

52. Андрейко С.С. Предотвращение газодинамических явлений при проведении уклонов, вскрывающих IV калийный горизонт, в условиях Старобинского месторождения калийных солей // Стратегия и процессы освоения георесурсов: сб. науч. тр. Пермь: Изд-во ГИ УрО РАН, 2014. - Вып. 12. - С. 227-229.

53. Андрейко С.С. Технология проведения уклонов, вскрывающих IV калийный горизонт, по выбросоопасным породам проходческими комбайнами избирательного действия в условиях рудника 2 РУ ОАО «Беларуськалий» // Актуальные проблемы повышения эффективности и безопасности эксплуатации горношахтного и нефтепромыслового оборудования: материалы II Междунар. науч.-практ. конф. «Горная и нефтяная электромеханика - 2015». - Пермь, 2015. - С. 125-131.

Please cite this article in English as:

Andreyko S.S., Bobrov D.A., Nesterov E.A., Lukyanets E.V. Estimation of Gas Content and Gas Dynamic Characteristics of Salt and Clayy-Carbonate Pills Rocks in the Mining Field of the the 2nd Ore Management JSC "Belaruskali". Perm Journal of Petroleum and Mining Engineering, 2020, vol.20, no.3, pp.270-279. DOI: 10.15593/2712-8008/2020.3.7

Просьба ссылаться на эту статью в русскоязычных источниках следующим образом:

Оценка газоносности и газодинамических характеристик пород соляных и глинисто-карбонатных пачек на шахтном поле рудника Второго рудоуправления ОАО «Беларуськалий» / С.С. Андрейко, Д.А. Бобров, Е.А. Нестеров, Е.В. Лукьянец // Недропользование. - 2020. - T.20, №3. - C.270-279. DOI: 10.15593/2712-8008/2020.3.7 